\title{
PERANCANGAN DAN REALISASI E-LOCK SYSTEM MENGGUNAKAN JARINGAN GSM
}

\section{DESIGN AND REALIZATION OF E-LOCK SYSTEM USING GSM NETWORK}

\author{
Febrian Hadiatna ${ }^{1}$, Ratna Susana ${ }^{2}$ \\ 1,2Jurusan Teknik Elektro, Fakultas Teknologi Industri, Institut Teknologi Nasional Bandung \\ Febrian_Hadiatna@yahoo.com, ${ }^{1}$ ratnassn@yahoo.com
}

\begin{abstract}
Abstrak
Dalam penelitian ini telah dirancang sistem keamanan elektronik untuk pintu (E-Lock System). Sistem ini menggunakan jaringan Global System for Mobile Communication (GSM) untuk mengirim perintah akses melalui layanan pesan singkat (SMS). Sistem ini menggunakan SMS, karena banyak orang telah menggunakan SMS untuk komunikasi sejak 10 tahun terakhir. Perangkat keras sistem menggunakan ATMega16 sebagai modul mikrokontroler dan wavecom sebagai modem GSM untuk mengirim atau menerima data SMS. Kata sandi digunakan pada sistem ini untuk mengakses kunci elektronik melalui SMS. Orang yang hanya memiliki izin akses ruangan dapat menggunakannya. Tidak hanya dapat mengakses pintu, E-Lock System memiliki kemampuan untuk menampilkan histori pengguna akses pintu dan mampu mendeteksi objek manusia di dalam ruangan. Proses pendeteksian objek dilakukan dengan sensor PIR yang telah terintegrasi dengan sistem ini. Banyak proses pengujian yang dilakukan pada sistem ini, seperti pengujian perangkat keras, pengujian transmisi data dan pengujian sistem terintegrasi. Hasil pengujian menunjukkan bahwa setiap menu pada sistem dapat diakses melalui SMS oleh pengguna. Data maksimal yang bisa ditampilkan dari menu histori adalah terbatas, hanya 8 pengguna terakhir.
\end{abstract}

Kata Kunci : electronic lock, jaringan GSM, SMS, password, sistem keamanan

\section{Abstract}

In this study has been designed an electronic security system for the door (E-Lock System). This system uses the Global System for Mobile Communication (GSM) network to send access commands through short messages service (SMS). This system uses SMS, because many people have been using SMS for communication since last 10 years. The system hardware uses ATMega16 as microcontroller and wavecom module as GSM modem to transmit or receive SMS data. Passwords is used on this system to access electronic key through SMS. People who only has room access permissions can use it. Not only can access the door, E-Lock System has ability to display the history of the user access the door and able to detect human objects in the room. Object detection process is done by PIR sensor which has been integrated with this system. Many of the testing processes performed on this system, such as hardware testing, data transmission testing and integrated system testing. Test results have shown that every menu on the system can be accessed through SMS by the user. The maximum data can be displayed from history menu is limited, only the last 8 users.

Keyword : electronic lock, GSM network, SMS, password, security system

\section{PENDAHULUAN}

E-Lock GSM system merupakan sistem kunci elektronik yang memanfaatkan jaringan GSM untuk mengirimkan perintah pengaksesan sistem. Dengan perkembangan teknologi SMS gateway sebagai perangkat yang dapat menggabungkan komputer dengan ponsel untuk mendistribusikan pesan-pesan melalui SMS, membuat fasilitas SMS pada perangkat mobile dapat digunakan untuk mengendalikan peralatan elektronik. Seperti halnya penelitian yang mengimplementasikan sistem 
rumah cerdas yang dapat mengendalikan peralatan elektronik menggunakan handphone melalui komunikasi SMS [1]. Pada penelitian lainnya [2], notifikasi melalui SMS digunakan untuk mengirimkan alarm kebakaran sebagai informasi kepada petugas pemadam kebakaran. Pada penelitian tersebut didapat keberhasilaan penerimaan alarm kebakaran dan titik awal terjadinya di atas $80 \%$ dengan waktu kurang dari 10 detik. Fasilitas SMS telah diimplementasikan pula pada sistem untuk mendeteksi logam pada penggilingan batu [3]. Notifikasi yang diterima berupa pemberitahuan melalui SMS bahwa telah terdeteksi adanya logam. Pada penelitian tersebut semua notifikasi dari SMS telah berhasil dikirimkan. Mengingat fasilitas SMS yang ada pada perangkat mobile dapat dimanfaatkan untuk kendali dan monitoring pada peralatan elektronik, maka penelitian ini mencoba mengembangkan sistem kunci elektronik menggunakan jaringan GSM.

Saat ini sistem kunci elektronik telah direalisasikan dengan teknologi yang ada dan dengan metoda yang berbeda-beda sesuai tingkat keamanan dan keperluan dari sistem itu sendiri. Beberapa diantaranya, mengembangkan sistem kunci elektronik dengan memanfaatkan fasilitas pada ponsel. Dengan menggunakan fasilitas bluetooth pada ponsel, telah berhasil dilakukan simulasi kunci elektronik dimana ponsel digunakan sebagai remote control dan komputer sebagai pusat kontrolnya [4]. Telah dikembangkan pula bank locker security system berbasis RFID dan teknologi GSM yang memanfaatkan SMS gateway [5]. Sistem tersebut bekerja berdasarkan pecocokan password pada mikrokontroler. Jika password yang dikirimkan melalui SMS sama dengan password pada mikrokontroler, maka kunci elektronik akan terbuka. Adapula kunci otomatis yang menggunakan sistem biometric yaitu face recognition sebagai password-nya [6]. Sistem mengidentifikasikan wajah untuk membuka atau menutup pintu secara otomatis ketika akan memasuki ruangan. Fasilitas SMS digunakan pula pada sistem tersebut, jika gambar wajah tidak teridentifikasi oleh sistem, maka sistem akan mengirimkan SMS kepada operator bahwa ada orang yang tidak teridentifikasi akan memasuki ruangan.

Dari beberapa tinjauan pustaka yang telah dibahas, sistem kunci elektronik telah menjadi salah satu bagian dari sistem keamanan yang banyak digunakan. Untuk itu penelitian ini mencoba mengembangkan pula suatu sistem kunci elektronik dengan merealisasikan E-Lock GSM system yang memanfaatkan fasilitas SMS pada perangkat mobile. E-Lock GSM system yang dikembangkan pada penelitian ini merupakan sistem kunci elektronik yang bertujuan untuk menjaga keamanan ruang. Sistem digunakan untuk ruangan yang memiliki pembatasan akses pengguna kunci ruangan. Hak akses diberikan dalam bentuk password, dimana hanya orang-orang tertentu saja yang dapat menggunakan sistem kunci elektronik ini. Untuk dapat mengakses kunci elektronik, maka nomor handphone pengguna harus terdaftar pada E-Lock GSM system. Dengan terdaftarnya nomor handphone pengguna, maka hanya SMS berupa password penggunalah yang dapat membuka kunci elektronik. Adanya pembatasan akses pengguna kunci elektronik ini, maka kondisi keamanan ruangan dapat terjaga dengan baik. Tidak hanya untuk mengakses kunci elektronik, sistem yang direalisasikan ini juga dapat menampilkan history pengguna yang telah melakukan akses kunci dan dapat mengetahui ada atau tidaknya aktifitas di dalam ruang. Permintaan history pengguna sistem dapat dilakukan hanya oleh operator sistem, melalui pesan SMS yang dikirimkannya ke E-Lock GSM system, dan sistem akan mengirimkan SMS yang berisi data pengguna ruang berupa nomor handphone dan waktu akses kunci. Selain itu, kapanpun operator juga dapat mengetahui kondisi ruangan melalui SMS, apakah ada aktifitas atau tidak. Hal ini dapat diketahui melalui sensor PIR yang dipasang di dalam ruang. Penggunaan SMS pada sistem ini dilakukan karena ada beberapa data pada mikrokontroler yang dapat diambil oleh operator melalui pesan SMS, yaitu kondisi ruangan dan history pengguna yang telah mengakses E-Lock GSM system.

Ada pembatasan masalah yang dilakukan pada penelitian ini, yaitu pembatasan pengguna sistem, karena pengguna harus terdaftar terlebih dahulu pada sistem. Pada penelitian ini hanya 
digunakan satu sensor PIR sehingga area objek yang dapat terdeteksi hanya sebatas kemampuan sensor PIR yang dipasang.

Adapun perumusan masalah pada penelitian ini adalah bagaimana merealisasikan E_lock system yang dapat diakses oleh pengguna ruang melalui pesan-pesan SMS yang dikirimkan dan bagaimana mikrokontroler mengolah data history pengguna serta mengirimkan SMS history pengguna dan kondisi ruangan kepada operator.

\section{PERANCANGAN DAN REALISASI E-LOCK SYSTEM}

\subsection{Deskripsi Umum Sistem}

Secara umum, sistem kunci elektronik memiliki 3 bagian utama seperti pada Gambar 1 berikut :

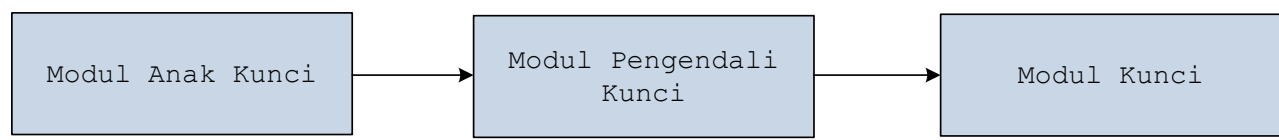

Gambar 1. Blok Diagram Sistem Kunci Elektronik Secara Umum

Penelitian ini merupakan pengembangan dari blok diagram sistem kunci elektronik pada Gambar 1 tersebut. Pada penelitian ini perangkat mobile digunakan sebagai modul untuk mengakses sistem kunci elektronik, dalam hal ini sebagai modul anak kunci. Fasilitas media SMS pada perangkat mobile digunakan untuk mengirimkan password pada modul pengendali kunci, dalam hal ini digunakan mikrokontroler ATMega16 yang telah terintegrasi dengan GSM module. Selanjutnya password yang diterima oleh mikrokontroler akan diproses untuk mengaktifkan modul kunci.

Secara garis besar, sistem kunci elektronik yang akan direalisasikan pada penelitian ini seperti yang diilustrasikan pada Gambar 2 berikut :

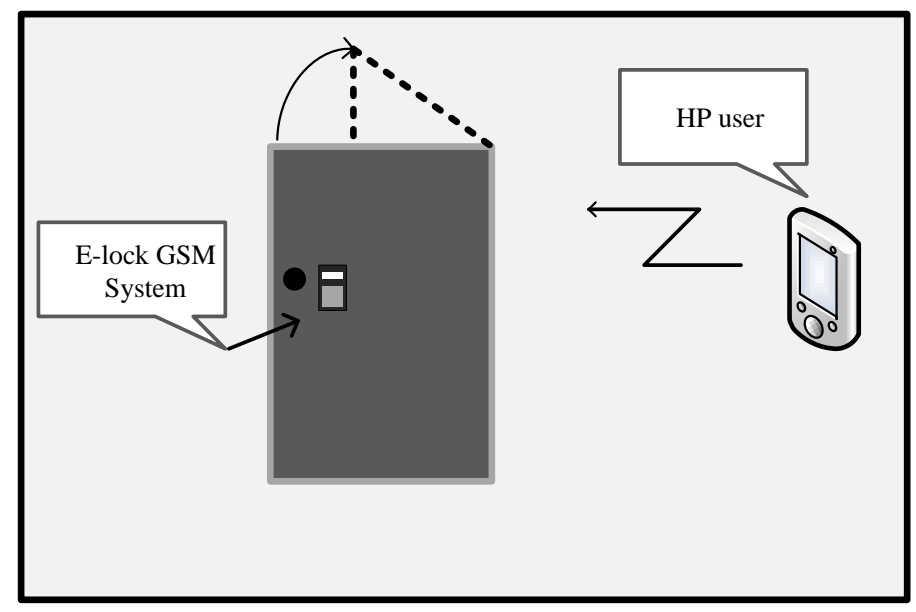

Gambar 2. Gambaran Umum Sistem

Selain untuk membuka kunci, sistem ini juga dibuat untuk dapat memberikan informasi kondisi ruangan yang diminta oleh operator melalui SMS dan juga dapat menampilkan histori dari pengaksesan yang telah dilakukan. Melalui menu history ini dapat diketahui siapa saja pengguna sistem yang pernah memasuki ruangan. 
Berdasarkan kebutuhan tersebut, maka sistem yang akan dibuat memiliki spesifikasi sebagai berikut :

1. Sistem menggunakan password yang ditanamkan pada program di dalam mikrokontroler.

2. Password untuk setiap pengguna sama, dan hanya diketahui oleh operator.

3. Sistem dapat memberikan informasi kondisi ruangan yang menggunakan kunci elektronik ini.

4. Sistem dapat memberikan informasi berupa histori pengguna yang telah melakukan akses kunci elektronik.

\subsection{Perancangan dan Realisasi Perangkat Keras (Hardware)}

Setelah menentukan spesifikasi sistem berdasarkan kebutuhan, barulah dilakukan perancangan dan realisasi perangkat keras dari sistem kunci elektronik itu sendiri. Berdasarkan spesifikasi tersebut, maka sistem kunci elektronik akan terdiri dari beberapa bagian, yaitu :

1. Kontroler sebagai otak dari sistem kunci elektronik.

2. Input sistem, yang terdiri dari :

- Keypad 4x3.

- Sensor PIR.

- Magnetic door sensor.

- Push button.

3. Output sistem, terdiri dari :

- Display LCD.

- Motor vibrator.

- Solenoid door lock.

4. Media transmisi, dengan menggunakan modem GSM.

Perancangan dan realisasi perangkat keras diawali dengan membuat arsitektur sistem sesuai dengan spesifikasi yang akan dibuat. Adapun arsitektur dari e-lock GSM system yang dirancang, seperti yang ditunjukkan pada Gambar 3 :

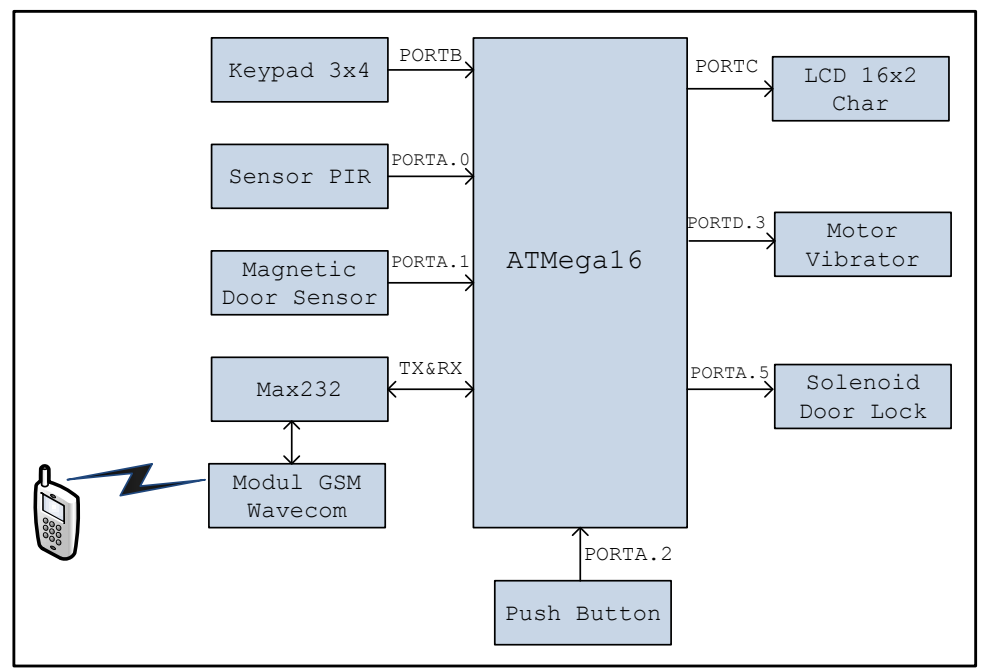

Gambar 3. Arsitektur E-Lock GSM System

Berdasarkan arsitektur pada Gambar 3, maka sistem ini akan terdiri dari beberapa blok, yaitu :

1. Perangkat mobile.

2. Mikrokontroler sebagai komponen pengendali sistem, dalam hal ini digunakan mikrokontroler ATMega 16.

3. Keypad digunakan untuk tombol emergency, setting sistem dan membaca history.

4. GSM modul untuk menerima perintah SMS yang dikirimkan dari perangkat mobile.

5. Push button untuk membuka kunci dari dalam ruangan.

6. Magnetic door sensor digunakan untuk mendeteksi apakah pintu terbuka atau tertutup. 
7. Sensor PIR untuk mendeteksi kondisi ruangan.

8. Solenoid door lock sebagai penggerak kunci pintu.

9. Display untuk menampilkan history dari pengaksesan kunci elektronik, menampilkan informasi kondisi pintu dan menu sistem.

Sesuai dengan arsitektur sistem, maka skematik sistem kunci elektronik secara keseluruhan seperti yang ditunjukkan pada Gambar 4 dan 5.

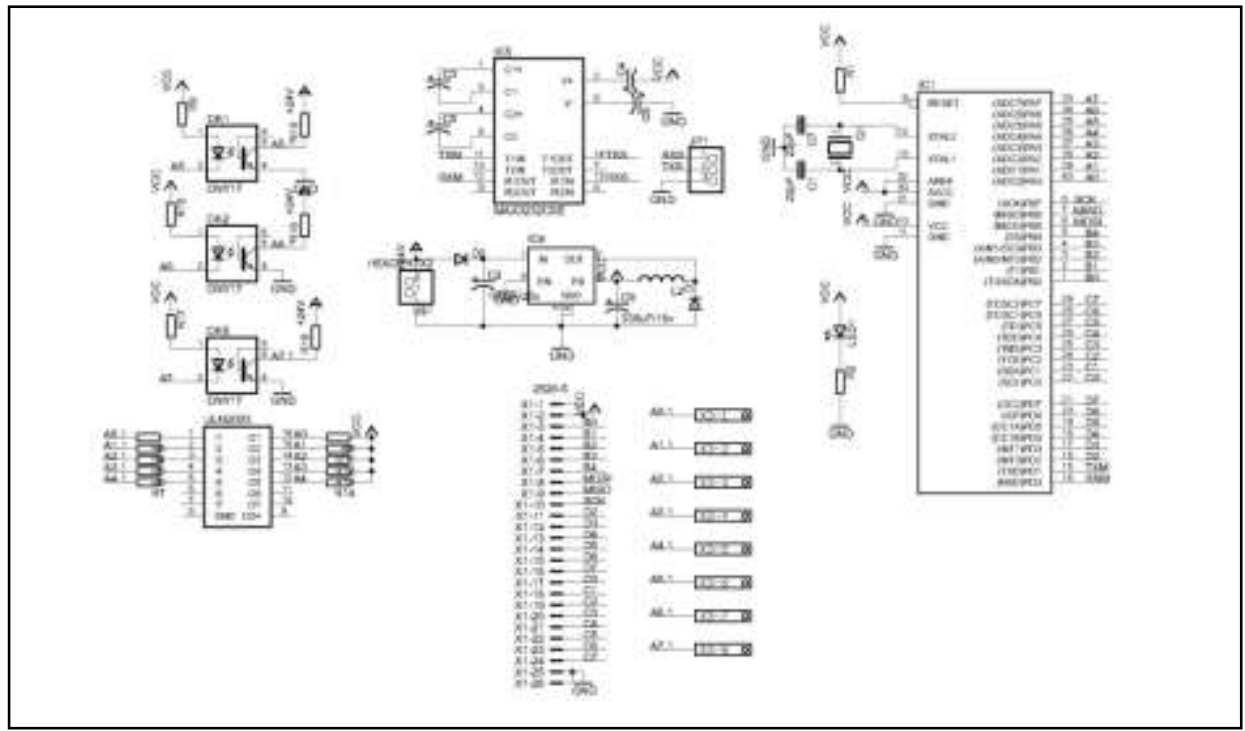

Gambar 4. Skematik Mikrokontroler - Modem GSM

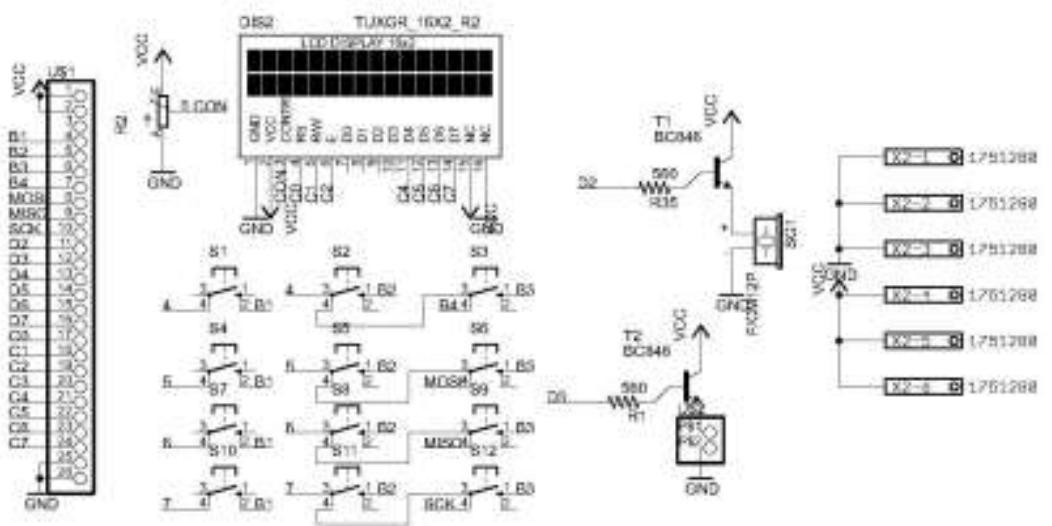

Gambar 5. Skematik Mikrokontroler - I/O Sistem 
Gambar 6 menunjukkan realisasi modul perangkat keras E-Lock GSM system :

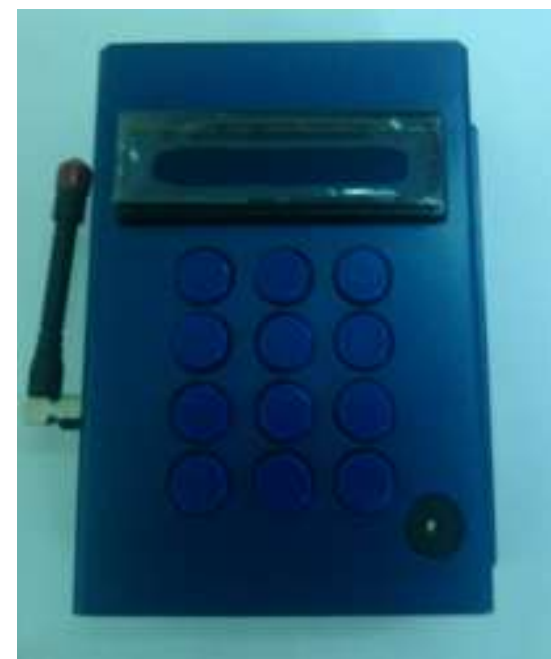

Gambar 6. Realisasi Perangkat Keras E-Lock GSM System

\subsection{Perancangan dan Realisasi Perangkat Lunak (Software)}

Perangkat lunak pada mikrokontroler dibuat untuk mengendalikan keseluruhan sistem kunci elektronik. Pada perancangan program CodeVision AVR, E-Lock system dirancang untuk pengguna SIM Card Pasca Bayar. Berikut ini Gambar 7 dan 8, menunjukkan flowchart dari program codevision AVR.

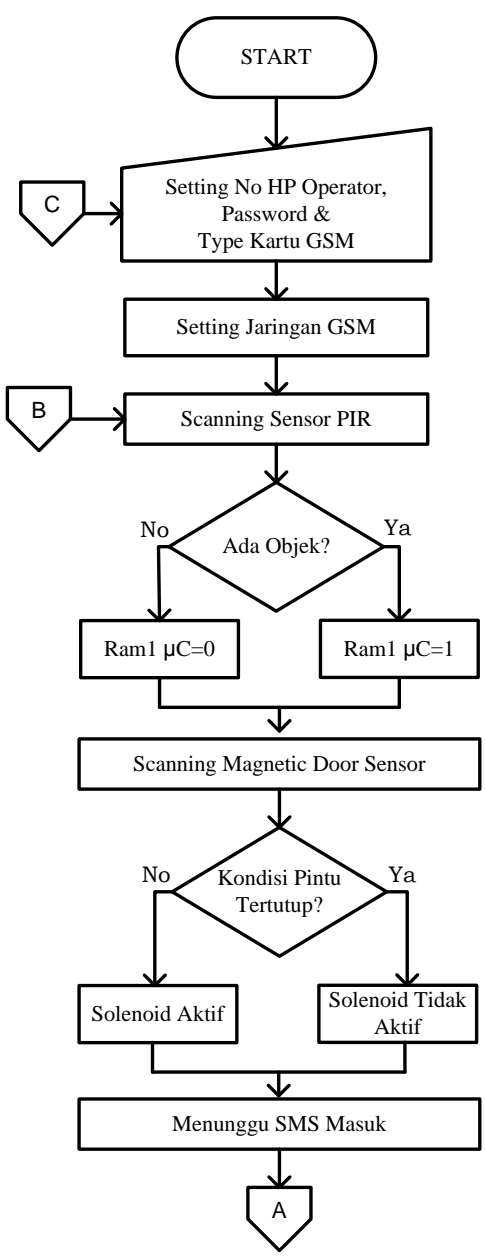

Gambar 7. Flowchart program CodeVision AVR 


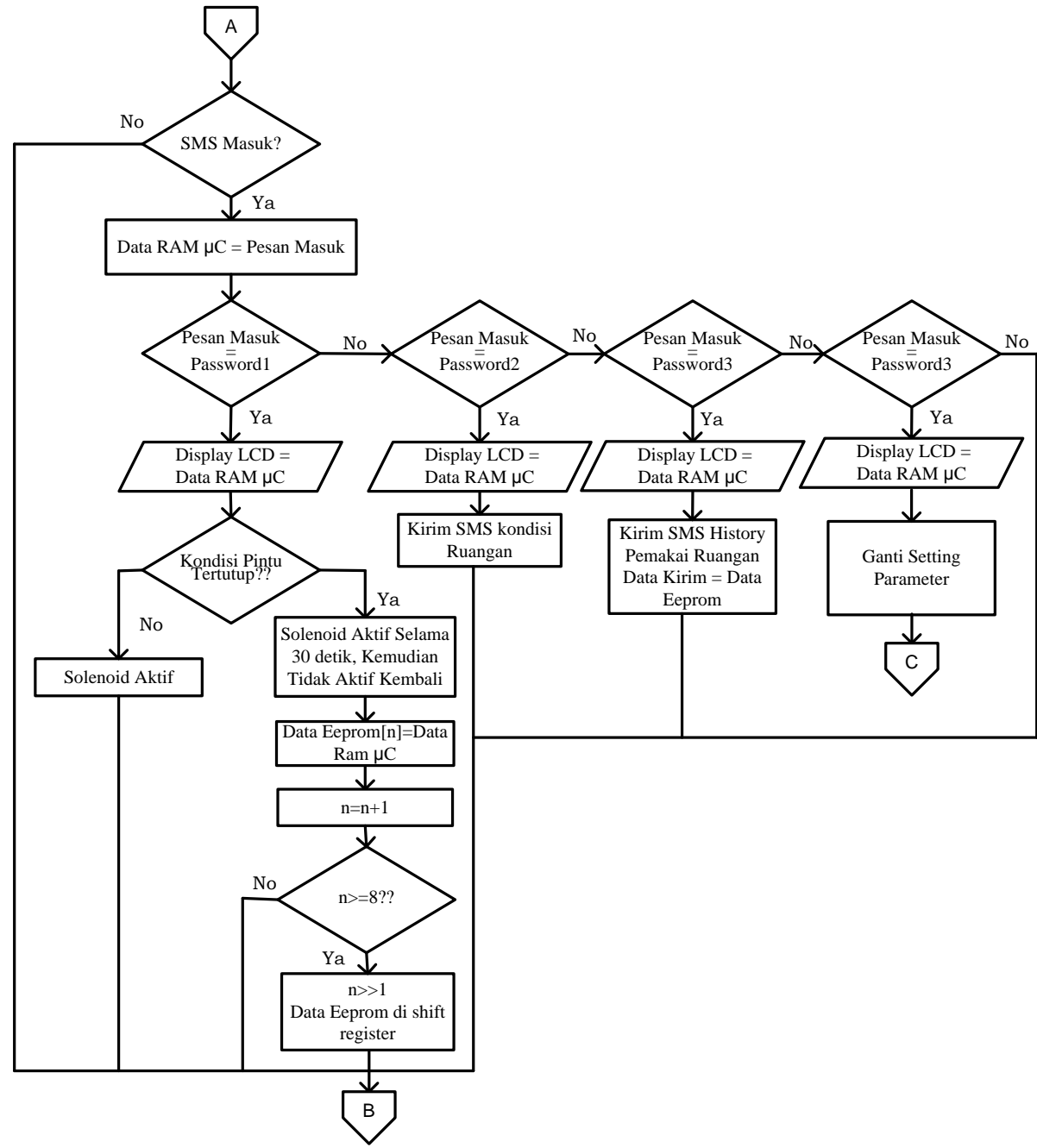

Gambar 8. Flowchart program Codevision AVR

\section{DATA PENGAMATAN DAN ANALISIS}

\subsection{Pengujian Perangkat Keras (Hardware)}

\subsubsection{Pengujian Sensor PIR}

Sensor PIR digunakan untuk mengetahui kondisi dari ruangan yang menggunakan sistem kunci elektronik. Sensor ini hanya untuk mendeteksi ada atau tidaknya aktifitas di dalam ruangan. Tabel 1 dan Tabel 2 menunjukkan hasil pendeteksian objek dengan sensor PIR.

Tabel 1. Hasil Pengujian Sensor PIR terhadap Keberadaan Objek

\begin{tabular}{|c|l|r|}
\hline No & \multicolumn{1}{|c|}{ Kondisi Objek } & $\begin{array}{c}\text { Output } \\
\text { Data }\end{array}$ \\
\hline 1 & Tidak Ada Objek & 0 Volt \\
\hline 2 & Objek Tidak Bergerak & 0 Volt \\
\hline 3 & Objek bergerak 1 Orang & 3,3 Volt \\
\hline 4 & Objek Bergerak lebih dari 1 orang & 3,3 Volt \\
\hline
\end{tabular}

Sedangkan pengujian area deteksi sensor PIR, dilakukan dengan memberikan objek bergerak pada jarak tertentu dari titik pusat sensor, seperti yang dapat dilihat pada Gambar 9. Data pengamatan diambil setiap perpindahan objek bergerak sejauh $50 \mathrm{~cm}$, mulai dari jarak $50 \mathrm{~cm}$ dari 
titik pusat sensor sampai $700 \mathrm{~cm}$ dari titik pusat sensor. Sensor diletakkan menempel di atas langilangit ruangan.

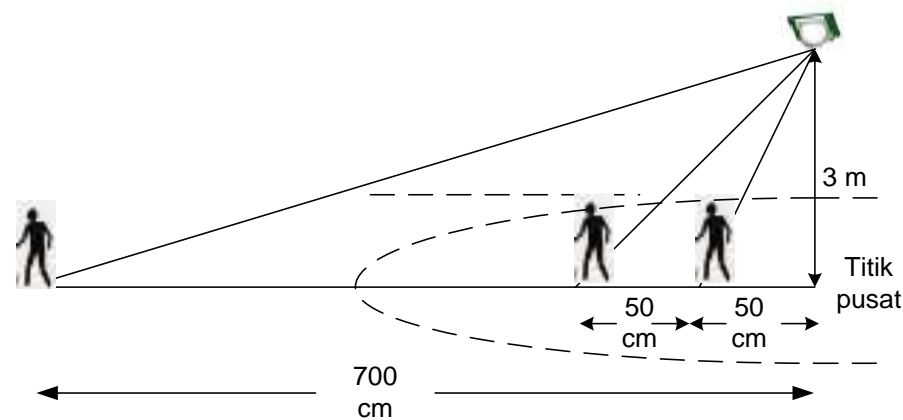

Gambar 9. Cara Pengujian Area Deteksi Sensor PIR

Tabel 2. Hasil Pengujian Area Deteksi Sensor PIR terhadap Objek

\begin{tabular}{|c|c|c|}
\hline No & $\begin{array}{c}\text { Jarak Objek Terhadap } \\
\text { Pusat Sensor }\end{array}$ & Output Data \\
\hline 1 & $50 \mathrm{~cm}$ & 3,3 Volt \\
\hline 2 & $100 \mathrm{~cm}$ & 3,3 Volt \\
\hline 3 & $150 \mathrm{~cm}$ & 3,3 Volt \\
\hline 4 & $200 \mathrm{~cm}$ & 3,3 Volt \\
\hline 5 & $250 \mathrm{~cm}$ & 3,3 Volt \\
\hline 6 & $300 \mathrm{~cm}$ & 3,3 Volt \\
\hline 7 & $350 \mathrm{~cm}$ & 3,3 Volt \\
\hline 8 & $400 \mathrm{~cm}$ & 3,3 Volt \\
\hline 9 & $450 \mathrm{~cm}$ & 0 Volt \\
\hline 10 & $500 \mathrm{~cm}$ & 0 Volt \\
\hline 11 & $550 \mathrm{~cm}$ & 0 Volt \\
\hline 12 & $600 \mathrm{~cm}$ & 0 Volt \\
\hline 13 & $650 \mathrm{~cm}$ & 0 Volt \\
\hline 14 & $700 \mathrm{~cm}$ & \\
\hline
\end{tabular}

Pada proses pengujian sensor PIR pada Tabel 1, proses pengujian dilakukan untuk menguji sensitivitas dari sensor PIR terhadap objek yang terdeteksi, dalam hal ini pergerakan orang di dalam ruang. Berdasarkan data pengamatan pada Tabel 1 menunjukkan bahwa sensor PIR sensitive terhadap adanya pergerakan makhluk hidup namun tidak dapat membedakan jumlah makhluk hidup yang terdeteksi. Berdasarkan data pengamatan Tabel 2, pada saat objek berada lebih jauh dari $400 \mathrm{~cm}$ di titik pusat sensor, PIR tidak dapat mendeteksi objek.

\subsubsection{Pengujian Magnetic Door Sensor}

Magnetic door sensor sebagai sensor untuk mendeteksi kondisi pintu ruangan dalam keadaan tertutup atau terbuka. Bagian Common pada sensor ini dihubungkan dengan Port A.1 pada mikrokontroler yang berfungsi untuk menerima input digital. Tabel 3 berikut ini menunjukkan data pengamatan dari magnetic door sensor:

Tabel 3. Hasil Pengujian Magnetic Door Sensor

\begin{tabular}{|c|c|c|c|c|c|}
\hline No & Kondisi Sensor & $\begin{array}{c}\text { Normally } \\
\text { Open }\end{array}$ & $\begin{array}{c}\text { Normally } \\
\text { Closed }\end{array}$ & Common & PORTA.1 \\
\hline 1 & Sensor Saling Bersentuhan & 0 Volt & 5 Volt & 5 Volt & 5 Volt \\
\hline 2 & Sensor Tidak Bersentuhan & 0 Volt & 5 Volt & 0 Volt & 0 Volt \\
\hline 3 & Sensor Saling Bersentuhan & 5 Volt & 0 Volt & 0 Volt & 0 Volt \\
\hline 4 & Sensor Tidak Bersentuhan & 5 Volt & 0 Volt & 5 Volt & 5 Volt \\
\hline
\end{tabular}


Berdasarkan data pengamatan pada Tabel 3, bagian Common pada magnetic door sensor akan terhubung dengan bagian Normally Open $(\mathrm{NO})$ pada saat sensor tidak bersentuhan atau menjauhi magnet, sedangkan pada saat sensor mendekati magnet bagian Common sensor akan terhubung dengan bagian Normally Closed (NC).

\subsubsection{Pengujian Solenoid Door Sensor}

Aktuator ini berfungsi sebagai tuas kunci pintu. Berikut ini Tabel 4, menunjukkan data pengamatan dari pengujian solenoida terhadap catu daya yang diberikan.

Tabel 4. Hasil Pengujian Aktuator Solenoida

\begin{tabular}{|c|c|c|}
\hline No & $\begin{array}{c}\text { Input } \\
\text { Tegangan }\end{array}$ & $\begin{array}{c}\text { Kondisi } \\
\text { Selenoida }\end{array}$ \\
\hline 1 & 0 Volt & Tidak Aktif \\
\hline 2 & 1 Volt & Tidak Aktif \\
\hline 3 & 2 Volt & Tidak Aktif \\
\hline 4 & 3 Volt & Tidak Aktif \\
\hline 5 & 4 Volt & Tidak Aktif \\
\hline 6 & 5 Volt & Aktif \\
\hline 7 & 6 Volt & Aktif \\
\hline 8 & 7 Volt & Aktif \\
\hline
\end{tabular}

Berdasarkan hasil pengukuran pada Tabel 4, kondisi aktifnya solenoida adalah ketika diberikan input +5 volt.

\subsection{Pengujian Perangkat Lunak (Software)}

Proses pengujian yang dilakukan pada perangkat lunak adalah untuk mengetahui bahwa SMS yang dikirimkan dapat diproses oleh perangkat keras sistem.

Tabel 5. Pengujian Aplikasi SMS

\begin{tabular}{|c|c|c|}
\hline No & Isi SMS Pengirim & Display LCD pada E-Lock \\
\hline 1 & Tes SMS & Tes SMS \\
\hline 2 & Pintu Buka & Pintu Buka \\
\hline 3 & Cek Objek & Cek Objek \\
\hline 4 & Cek History & Cek History \\
\hline
\end{tabular}

Gambar 10 berikut ini merupakan contoh hasil tampilan SMS pada display E-Lock system.

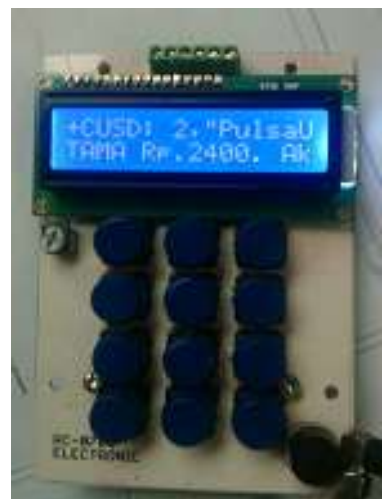

Gambar 10. Tampilan SMS pada Display E-Lock GSM System

\subsection{Pengujian Sistem Secara Keseluruhan}

Hasil pengujian sistem secara keseluruhan ini bertujuan untuk melihat sejauh mana keberhasilan sistem setelah terintegrasi keseluruhan hardware dan software-nya. Proses pengujian 
yang dilakukan pada sistem secara keseluruhan adalah dengan mengirimkan SMS tertentu sesuai dengan format password yang telah dimasukan datanya pada sistem kunci elektronik, kemudian melihat kondisi yang terjadi pada sistem kunci elektronik. Data pengamatan dari pengujian sistem secara keseluruhan dapat dilihat pada Tabel 6.

Tabel 6. pengujian sistem kunci elektronik

\begin{tabular}{|c|c|c|c|c|c|c|c|}
\hline No & $\begin{array}{c}\text { Format } \\
\text { Password }\end{array}$ & $\begin{array}{c}\text { Objek di } \\
\text { Ruangan }\end{array}$ & $\begin{array}{c}\text { Kondisi } \\
\text { Pintu }\end{array}$ & $\begin{array}{c}\text { Kondisi } \\
\text { PIR }\end{array}$ & $\begin{array}{c}\text { Kondisi } \\
\text { PINA }\end{array}$ & $\begin{array}{c}\text { Kondisi } \\
\text { Solenoida }\end{array}$ & $\begin{array}{c}\text { SMS di HP } \\
\text { User }\end{array}$ \\
\hline 1 & Cek Pulsa & - & - & - & - & - & $\sqrt{ }$ \\
\hline 2 & Buka Pintu & - & Tertutup & - & 0 & Aktif & - \\
\hline 3 & Buka Pintu & - & Terbuka & - & 1 & Tidak Aktif & - \\
\hline 4 & Cek Ruang & Ada & Tertutup & 1 & 0 & Aktif & $\sqrt{ }$ \\
\hline 5 & Cek Ruang & Tidak Ada & Tertutup & 0 & 0 & Aktif & $\sqrt{ }$ \\
\hline 6 & Cek Ruang & Ada & Terbuka & 1 & 1 & Tidak Aktif & $\sqrt{ }$ \\
\hline 7 & Cek Ruang & Tidak Ada & Terbuka & 0 & 1 & Tidak Aktif & $\sqrt{ }$ \\
\hline 8 & Cek History & - & - & - & - & - & $\sqrt{ }$ \\
\hline 9 & Format Salah & - & - & - & - & - & - \\
\hline
\end{tabular}

Berdasarkan data pengamatan pada Tabel 6, menunjukkan bahwa sistem kunci elektronik yang dirancang telah berhasil direalisasikan sesuai dengan spesifikasi yang diinginkan. Namun selama proses pengujian berlangsung ada beberapa hal yang masih perlu diperhatikan, diantaranya:

1. Posisi antenna pada modem GSM memiliki pengaruh cukup besar, terutama saat catu daya yang digunakan memiliki spesifikasi arus cukup kecil (kurang dari 1 Ampere). Hal ini disebabkan proses komunikasi GSM memerlukan arus cukup besar, sehingga pada saat posisi antenna tidak benar maka komunikasi GSM akan memerlukan arus yang lebih besar dari saat kondisi komunikasi secara normalnya.

2. Pada saat proses pengecekan nominal pulsa berlangsung, informasi yang diterima oleh modul GSM tidak selalu dapat dikirimkan kepada handphone pengguna, namun informasi nominal saldo selalu diterima oleh modul GSM berdasarkan display LCD yang terdapat pada kunci elektronik.

3. Informasi nominal saldo yang diinformasikan pada handphone pengguna menampilkan data yang kurang akurat, hal ini dikarenakan data yang dikirimkan merupakan data nominal saldo sebelum dikurangi dengan biaya pengiriman data kepada handphone pengguna.

4. Proses menyimpanan data history pengguna akses ruangan terbatas hanya sampai dengan 8 pengguna akses ruangan terbaru. Kemampuan dalam menyimpan history tersebut berkaitan dengan kapasitas EEPROM yang terdapat pada mikrokontroler. Untuk ATmega16, EEPROM yang dimiliki 512 byte sehingga jika 1 buah karakter ASCII yang digunakan memiliki data sebesar 1 byte, maka kemampuan EEPROM ATmega16 dalam menyimpan data adalah sebesar 512 karakter. Pada saat proses penyimpanan data pengguna ruangan, jumlah karakter data yang akan disimpan dari setiap pengguna ruangan adalah sebanyak 38 karakter, sehingga jika diasumsikan kapasitas penyimpanan data sampai dengan 8 orang pengguna terbaru maka besarnya data yang disimpan adalah sebesar 304 byte. Sedangkan untuk sisa data penyimpanan EEPROM yang berjumlah 208 byte akan digunakan untuk keperluan lainnya, seperti untuk penyimpanan data nomor handphone operator, kode password dan lain-lain. 


\section{KESIMPULAN}

Berdasarkan hasil pengujian terhadap perangkat kunci elektronik, dapat disimpulkan bahwa perangkat kunci elektronik telah berfungsi sesuai dengan yang diharapkan, namun masih belum bersifat stabil, hal ini di karenakan oleh beberapa faktor, diantaranya:

1. Pemberian catu daya memiliki pengaruh terhadap proses pengiriman data informasi. Pada penggunaan catu daya kurang dari 1 Ampere, akan mengakibatkan perangkat kunci elektronik kurang stabil dalam mengirimkan informasi data sehingga informasi data tidak dapat terkirimkan informasinya.

2. Berdasarkan data Tabel 1 pada pengujian sensor PIR, menunjukkan bahwa kemampuan dari sensor PIR dalam mendeteksi adanya objek adalah berdasarkan pada pergerakan objek, sehingga pada saat objek dalam kondisi diam maka sensor PIR tidak dapat mendeteksi objek.

3. Pemilihan provider kartu GSM yang digunakan mempengaruhi proses pengiriman data SMS. Pada penggunaan kartu GSM dengan provider yang telah memiliki jaringan pengiriman data yang luas, proses pengiriman informasi data SMS akan lebih banyak terkirim.

4. Kemampuan perangkat kunci elektronik dalam menyimpan informasi data history yang ditampilkan dan data pengguna sistem dipengaruhi oleh kapasitas EEPROM dari mikrokontroler yang digunakan.

\section{DAFTAR PUSTAKA}

[1] A.O, Oke. J.O, Emuoyibofarhe dan A.B, Adetunji. 2013. Development of a GSM based Control System for Electrical Appliances. International Journal of Engineering and Technology. Volume 3. No. 4.

[2] Susana, Ratna. Darlis, Arsyad R. dan Aqli, Sayidino. 2015. Implementasi Wireless Sensor Network Prototype sebagai Fire Detector menggunakan Arduino Uno. Jurnal Elektro dan Telekomunikasi Terapan (JETT). Volume 2. Nomor 1. Halaman $53-60$.

[3] De Lama, Aldino. Sunarya, Unang dan Novianti, Atik. 2016. Deteksi Logam pada Penggilingan Batu Berbasis SMS Gateway dan Mikrokontroler. Jurnal Elektro dan Telekomunikasi Terapan (JETT). Volume 3. Nomor 2. Halaman 370 - 378.

[4] Neforawati, Indri dan Saragih, Hoga. 2008. Simulasi Kunci Elektronik dengan Enkripsi Melalui Bluetooth pada Ponsel. CommIT. Vol. 2. No. 2. Halaman 137 - 141.

[5] Ramani, R. et al. 2012. Bank Locker Security System based on RFID and GSM Technology. International Journal of Computer Applications. Volume 57. No. 18. (0975 - 8887).

[6] Yugashini, I. et al. 2013. Design and Implementation of Automated Door Accessing System with Face Recognation. International Journal of Science and Modern Engineering (IJISME). Volume-1. Issue-2. ISSN : $2319-6386$. 